This PDF is a selection from a published volume from the National Bureau of Economic Research

Volume Title: The Risks of Financial Institutions

Volume Author/Editor: Mark Carey and René M. Stulz, editors

Volume Publisher: University of Chicago Press

Volume ISBN: 0-226-09285-2

Volume URL: http://www.nber.org/books/care06-1

Conference Date: October 22-23, 2004

Publication Date: January 2007

Title: Systemic Risk and Regulation

Author: Franklin Allen, Douglas Gale

URL: http://www.nber.org/chapters/c9613 


\title{
Systemic Risk and Regulation
}

\author{
Franklin Allen and Douglas Gale
}

\subsection{Introduction}

The experience of banking crises in the 1930s was severe. Before this, assuring financial stability was primarily the responsibility of central banks. The Bank of England had led the way. The last true panic in England was associated with the collapse of the Overend, Gurney, and Company in 1866. After that the Bank avoided crises by skillful manipulation of the discount rate and supply of liquidity to the market. Many other central banks followed suit, and by the end of the nineteenth century crises in Europe were rare. Although the Federal Reserve System was founded in 1914, its decentralized structure meant that it was not able to effectively prevent banking crises. The effect of the banking crises in the 1930s was so detrimental that in addition to reforming the Federal Reserve System the United States also imposed many types of banking regulation to prevent systemic risk. These included capital adequacy standards, asset restrictions, liquidity requirements, reserve requirements, interest rate ceilings on deposits, and restrictions on services and product lines. Over the years many of these regulations have been removed. However, capital adequacy requirements in the form of the Basel agreements remain.

We are grateful to our discussant Charles Calomiris and other participants at the NBER Conference on "The Risks of Financial Institutions" held in Woodstock, Vermont, October 22-23, 2004, our discussant Martin Hellwig and other participants at the Center for Financial Studies (CFS) Conference on "Risk Transfer between (Re-)Insurers, Banks, and Markets" held in Frankfurt, June 10-11, 2005, and our discussant Charles Kahn and other participants at the Bank of Portugal Conference on "Financial Fragility and Bank Regulation" held in Lisbon, June 24-25, 2005. Finally, we also thank the editors, Mark Carey and René Stulz, for their very helpful comments on an earlier version, and Florian Preis for pointing out an error in an earlier version. 
If properly designed and implemented, capital regulations may reduce systemic risk. However, the growing importance of credit risk transfer has raised concerns about whether regulation as currently implemented does increase financial stability. The evidence reviewed subsequently suggests that there is a transfer of risk from the banks to insurance companies. One view is that this credit risk transfer is desirable because it allows diversification between different sectors of the financial system that cannot be achieved in other ways. On the other hand, if the transfer arises because of ill-designed regulations it may be undesirable. For example, regulatory arbitrage between the banking and insurance sectors could conceivably lead to an increase in risk in the insurance sector, which increases overall systemic risk. As Hellwig $(1994,1995,1998)$ has repeatedly argued, attempts to shift risks can lead to a situation where these risks come back in the form of counterparty credit risk.

The purpose of this paper is to consider both arguments. We show first that diversification across sectors can lead to an optimal allocation of resources, and second that poorly designed and implemented capital regulation can lead to an increase in systemic risk.

Our analysis builds on our previous work on financial crises (see, e.g., Allen and Gale 1998, 2000a-c, 2003, 2004a-b, and Gale 2003, 2004). In Allen and Gale (2004b) we argued that financial regulation should be based on a careful analysis of the market failure that justifies government intervention. We developed a model of intermediaries and financial markets in which intermediaries could trade risk. It was shown that, provided financial markets and financial contracts are complete, the allocation is incentive efficient. When contracts are incomplete-for example, if the banks use deposit contracts with fixed promised payments - then the allocation is constrained efficient. In other words, there is no justification for regulation by the government. In order for regulation to be justified markets must be incomplete. As in standard theories of government regulation, it is first necessary to identify a market failure to analyze intervention. In Allen and Gale (2003) we suggested that the standard justification for capital regulation, namely that it controls moral hazard arising from deposit insurance, is not a good motivation. The two policies must be jointly justified and the literature does not do this.

There is a small but growing literature on credit risk transfer. The first part considers the impact of credit risk transfer on the allocation of resources when there is asymmetric information. Morrison (2005) shows that a market for credit derivatives can destroy the signalling role of bank debt and lead to an overall reduction in welfare as a result. He suggests that disclosure requirements for credit derivatives can help offset this effect. Nicolo and Pelizzon (2004) show that if there are banks with different abilities to screen borrowers, then good banks can signal their type using first-todefault basket contracts, which are often used in practice. These involve a payment to the protection buyer, if any, of a basket of assets defaults. Only 
protection sellers with very good screening abilities will be prepared to use such contracts. Chiesa (2004) considers a situation wherein banks have a comparative advantage in evaluating and monitoring risks but limited riskbearing capacity. Credit risk transfer improves efficiency by allowing the monitored debt of large firms to be transferred to the market while banks can use their limited risk-bearing capacity for loans to small businesses. In contrast to these papers, our paper focuses on the situation where there is symmetric information, and shows how credit risk transfer can improve the allocation of resources through better risk sharing.

The second part of the literature focuses on the stability aspects of credit risk transfer. Wagner and Marsh (2004) consider the transfer of risk between banking and nonbanking sectors. They find that the transfer of risk out of a relatively fragile banking sector leads to an improvement in stability. Wagner (2005b) develops a model where credit risk transfer improves the liquidity of bank assets. However, this can increase the probability of crises by increasing the risks that banks are prepared to take. Wagner (2005a) shows that the increased portfolio diversification possibilities introduced by credit risk transfer can increase the probability of liquiditybased crises. The reason is that the increased diversification leads banks to reduce the amount of liquid assets they hold and increase the amount of risky assets. In contrast to these contributions, in our paper the focus is on the role of poorly designed regulation and its interaction with credit risk transfer in increasing systemic risk.

The rest of the paper proceeds as follows. We start in section 7.2 by considering the institutional background of credit risk transfer. We consider the evidence on how important risk transfers are quantitatively and which entities they occur between. Section 7.3 develops a model with a banking sector where consumers deposit their funds and firms borrow and repay these loans with some probability. There is also an insurance sector. Some firms have an asset that may be damaged. They require insurance to allow this asset to be repaired if it is damaged. The equilibrium with complete markets and contracts is characterized. In this case, complete markets allow full risk sharing. Section 7.4 develops an example with incomplete markets and contracts and shows how inefficient capital regulation can increase systemic risk. Finally, section 7.5 contains concluding remarks.

\subsection{Institutional Background on Credit Risk Transfer}

Credit risk has been transferred between parties for many years. Bank guarantees and credit insurance provided by insurance companies, for example, have a long history. Securitization of mortgages occurred in the 1970s. Bank loans were syndicated in the 1970s, and secondary markets for bank loans developed in the 1980s. In recent years a number of other methods of risk transfer have come to be widely used.

In table 7.1, Bank of International Settlements (BIS 2003) shows the 
Table 7.1

Size of credit risk transfer markets (in billions of U.S.\$)

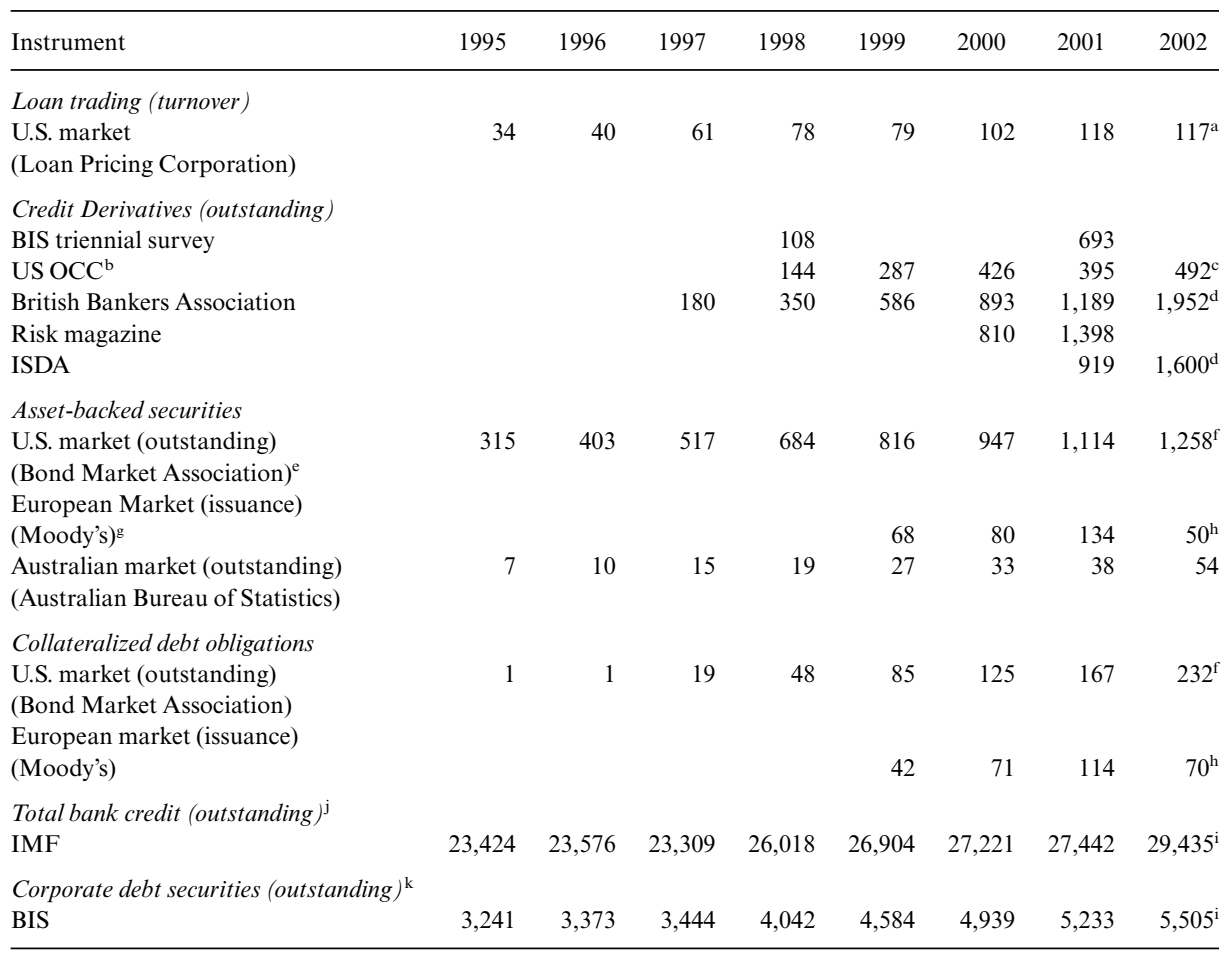

Source: BIS (2003).

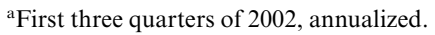

${ }^{b}$ Holdings of U.S. commercial banks.

c Second quarter of 2002.

${ }^{\mathrm{d}}$ Forecast for 2002.

${ }^{\mathrm{e}}$ Excluding CBOs/CDOs.

${ }^{\mathrm{f}}$ September 2002.

${ }^{\mathrm{g}} \mathrm{ABSs}$ and MBSs.

${ }^{\text {h}}$ First half of 2002.

${ }^{\mathrm{i}}$ June 2002.

${ }^{\mathrm{j}}$ Domestic and international credit to nonbank borrowers (United States, United Kingdom, Japan, Canada, Euro area).

${ }^{\mathrm{k}}$ Debt securities issued in international and domestic markets, nonfinancial corporates.

size of credit risk transfer markets using various instruments from 19952002. Institutions transferring risk out are referred to as "risk shedders" while institutions taking on risk on are referred to as "risk buyers." One important class of instrument is credit derivatives. An example of these is credit default swaps. These are bilateral contracts where the risk shedder pays a fixed periodic fee in exchange for a payment contingent on an event 
such as default on a reference asset or assets. The contingent payment is provided by the risk buyer. With asset-backed securities, loans, bonds, or other receivables are transferred to a special purpose vehicle (SPV). The payoffs from these assets are then paid out to investors. The credit risk of the instruments in the SPV is borne by the investors. The underlying pool of assets in asset-backed securities is relatively homogeneous. Collateralized debt obligations also use an SPV but have more heterogeneous assets. Payouts are tranched, with claims on the pools separated into different degrees of seniority in bankruptcy and timing of default. The equity tranche is the residual claim and has the highest risk. The mezzanine tranche comes next in priority. The senior tranche has the highest priority and is often AAA rated.

It can be seen from table 7.1 that the use of all types of credit risk transfer has increased substantially. The growth has been particularly rapid in credit derivatives and collateralized debt obligations, however. Despite this rapid growth, a comparison of the outstanding amounts of credit risk transfer instruments with the total outstanding amounts of bank credit and corporate debt securities shows that they remain small in relative terms.

In table 7.2, British Bankers Association (BBA 2002) shows the buyers of credit protection in panel A and the sellers in panel B. From panel A it can be seen that the buyers are primarily banks. Securities houses also play

Table 7.2

Buyers and sellers of credit protection (percent of market)

\begin{tabular}{|c|c|c|}
\hline & End of 1999 & End of 2001 \\
\hline \multicolumn{3}{|c|}{ A. Buyers of credit protection } \\
\hline Banks & 63 & 52 \\
\hline Securities houses & 18 & 21 \\
\hline Hedge funds & 3 & 12 \\
\hline Corporates & 6 & 4 \\
\hline Insurance companies ${ }^{\mathrm{a}}$ & 7 & 6 \\
\hline Mutual funds & 1 & 2 \\
\hline Pension funds & 1 & 1 \\
\hline Government/Export credit agencies & 1 & 2 \\
\hline \multicolumn{3}{|c|}{ B. Sellers of credit protection } \\
\hline Banks & 47 & 39 \\
\hline Securities houses & 16 & 16 \\
\hline Hedge funds & 5 & 5 \\
\hline Corporates & 3 & 2 \\
\hline Insurance companies ${ }^{\mathrm{a}}$ & 23 & 33 \\
\hline Mutual funds & 2 & 3 \\
\hline Pension funds & 3 & 2 \\
\hline Government/Export credit agencies & 1 & 0 \\
\hline
\end{tabular}

Source: BBA Credit Derivatives Report 2001/2002.

${ }^{a}$ Includes monoline companies and reinsurers. 
an important role. Hedge funds went from being fairly insignificant in 1999 to being significant in 2001. Corporates, insurance companies, and the other buyers do not constitute an important part of demand in the market. From panel B, it can be seen that banks are also important sellers of credit protection. In contrast to their involvement as buyers, the role of insurance companies as sellers is significant. Securities houses also sell significant amounts, while the remaining institutions play a fairly limited role. The results of a survey contained in Fitch (2003) are consistent with table 7.2. They found that the global insurance sector had a net seller position after deducting protection bought of $\$ 283$ billion. The global banking industry purchased $\$ 97$ billion of credit protection. A significant amount of risk is thus being transferred into the insurance industry from banks and other financial institutions. However, BIS (2005) reports that credit risk transfer investments made up only 1 percent of insurers' total investments, and that their financial strength is not threatened by their involvement in these types of investment.

As discussed in the introduction, these figures raise the important issue of why these transfers of risk are taking place. Is it the result of financial institutions seeking to diversify their risk? Alternatively, is it the result of regulatory arbitrage, and if so, can this arbitrage lead to a concentration of risk that increases the probability of systemic collapse?

We turn next to the role of credit risk transfer in allowing diversification between different sectors of the economy.

\subsection{Diversification through Credit Risk Transfer}

We use a simple Arrow-Debreu economy to illustrate the welfare properties of credit risk transfer when markets are complete. First we describe the primitives of the model, which will be used here and in following sections. Then we describe an equilibrium with complete markets. We note that the fundamental theorems of welfare economics imply that risk sharing is efficient and, hence, there is no role for government regulation in this setting. It is also worth noting that there is no role for capital. More precisely, the capital structure is irrelevant to the value of the firm, as claimed by Modigliani and Miller, and in particular there is no rationale for capital regulation. (This point has been made repeatedly by Gale 2003, 2004; Allen and Gale 2003; and Gale and Özgür 2005).

The model serves two purposes. First, it serves to show how credit risk transfers can promote efficient risk sharing if we interpret the markets for contingent securities in the Arrow-Debreu model as derivatives or insurance contracts. Secondly, it provides a benchmark for the discussion of incomplete markets that follows. By contrast with the Arrow-Debreu model, there is no reason to think that the equilibrium allocation of risk bearing is efficient when markets are incomplete. So, incompleteness of markets pro- 
vides a potential role for regulation to improve risk sharing. However, as we shall see, a badly designed policy of capital regulation may lead to greater instability.

\subsubsection{The Basic Model}

There are three dates $t=0,1,2$ and a single, all-purpose good that can be used for consumption or investment at each date. There are two securities, one short and one long. The short security is represented by a storage technology: one unit at date $t$ produces one unit at date $t+1$. The long security is represented by a constant-returns-to-scale investment technology that takes two periods to mature: one unit invested in the long security at date 0 produces $R>1$ units of the good at date 2 (and nothing at date 1). This simple structure provides a tradeoff between liquidity and the rate of return (the yield curve). Banks would like to earn the higher return offered by the long asset, but that may cause problems, because the banks' liabilities (demand deposits) are liquid.

In addition to these securities, banks and insurance companies have distinct profitable investment opportunities. Banks can make loans to firms that succeed with probability $\beta$. More precisely, each firm borrows one unit at date 0 and invests in a risky venture that produces $B_{H}$ units of the good at date 2 if successful and $B_{L}$ if unsuccessful. There is assumed to be an infinite supply of such firms, so the banks take all the surplus. (In effect, these "firms" simply represent a constant-returns-to-scale investment technology for the banks.) Because we are only interested in nondiversifiable risks, we assume that the loans made by an individual bank are perfectly correlated: either they all pay off or none do. This is a gross simplification that does not essentially affect the points we want to make.

The bank's other customers are depositors, who have one unit of the good at date 0 and none at dates 1 and 2. Depositors are uncertain of their preferences: with probability $\lambda$ they are early consumers, who only value the good at date 1 and with probability $1-\lambda$ they are late consumers, who only value the good at date 2 . The utility of consumption is represented by a utility function $U(c)$ with the usual properties. We normalize the number of consumers to 1 . The form of the depositors' preferences provides a demand for liquidity and explains why the bank must offer a contract that allows the option of withdrawing either at date 1 or date 2 .

The insurance companies have access to a large number of firms, whose measure is normalized to one. Each firm owns an asset that produces $A$ units of the good at date 2 . With probability $\alpha$ the asset suffers some damage at date 1 . Unless this damage is repaired, at a cost of $C$, the asset becomes worthless and will produce nothing at date 2 . The firms also have a unit endowment at date 0 which the insurance company invests in the short and long securities in order to pay the firms' damages at date 1. The risks to different firms are assumed to be independent, so the fraction of firms 
suffering damage in any state is equal to the probability $\alpha$. More importantly, the risks faced by the insurance and banking sectors are not perfectly correlated, so there are some gains from sharing risks. This in turn provides the potential for gains from credit risk transfer.

Finally, we introduce a class of risk-neutral investors who provide capital to the insurance and banking sectors. Although investors are risk neutral, we assume that their consumption must be nonnegative at each date. This is a crucial assumption. Without it, the investors could absorb all risk and provide unlimited liquidity, and the problem of achieving efficient risk sharing would be trivial. The assumption of nonnegative consumption, on the other hand, implies that investors can only provide risk-sharing services to banks and/or insurance companies if they invest in real assets that provide future income streams. The investor's utility function is defined by

$$
u\left(c_{0}, c_{1}, c_{2}\right)=\rho c_{0}+c_{1}+c_{2},
$$

where $c_{t} \geq 0$ denotes the investor's consumption at date $t=0,1,2$. The constant $\rho>E(R)$ represents the investor's opportunity cost of funds. For example, the investors may have access to investments that yield a very high rate of return but are very risky and very illiquid. Markets are segmented, and other agents do not have access to these assets. Banks cannot include these assets in their portfolios, so they cannot earn as much on the capital invested in the bank as the investors could. This gap defines the economic cost of capital: in order to compensate the investors for the opportunity cost of the capital they invest, the depositors must take a smaller payout in order to subsidize the earnings of the investors.

We can assume without loss of generality that the role of investors is simply to provide capital to the intermediary through a contract $e=\left(e_{0}, e_{1}\right.$, $e_{2}$ ) where $e_{0} \geq 0$ denotes the investor's supply of capital at date $t=0$, and $e_{t} \geq 0$ denotes the investor's consumption at dates $t=1,2$. While it is feasible for the investors to invest in assets at date 0 and trade them at date 1 , it can never be profitable for them to do so in equilibrium. More precisely, the no-arbitrage conditions ensure that profits from trading assets are zero or negative at any admissible prices, and the investor's preferences for consumption at date 0 imply that the investors will never want to invest in assets at date 0 and consume the returns at dates 1 and 2. An investor's endowment consists of a large (unbounded) amount of the good $X_{0}$ at date 0 and nothing at dates 1 and 2 . This assumption has two important implications. First, since the investors have an unbounded endowment at date 0 there is free entry into the capital market, and the usual zero-profit condition implies that investors receive no surplus in equilibrium. Second, the fact that investors have no endowment (and nonnegative consumption) at dates 1 and 2 implies that their capital must be converted into assets in order to provide risk sharing at dates 1 and 2 . We can then write the investors' utility in the form: 


$$
u\left(e_{0}, e_{1}, e_{2}\right)=\rho X_{0}-\rho e_{0}+e_{1}+e_{2} .
$$

The most plausible structure of uncertainty is one that allows for some diversification and some aggregate risk. This is achieved by assuming that the proportions of damaged firms for the insurance sector and failing firms for the banking sector equal the probabilities $\alpha$ and $\beta$, respectively, and that these probabilities are themselves random. For the purposes of illustration, suppose that $\alpha$ and $\beta$ each take on two values, $\alpha_{H}$ and $\alpha_{L}$ and $\beta_{H}$ and $\beta_{L}$. Nothing would change if we adopted a more general structure, but this is enough to make the essential points. Note that $\alpha$ and $\beta$ are not perfectly correlated. We may observe any combination of values, $\left(\alpha_{H}, \beta_{H}\right),\left(\alpha_{L}, \beta_{H}\right)$, $\left(\alpha_{H}, \beta_{L}\right)$, or $\left(\alpha_{L}, \beta_{L}\right)$. The uncertainty in the model is resolved at the beginning of date 1 . Banks' depositors learn whether they are early or late consumers and banks learn whether the firms borrowing from them have failed. Insurance companies learn which firms' assets have suffered damage.

\subsubsection{An Arrow-Debreu Equilibrium}

In this section we provide a sketch of the definition of Arrow-Debreu equilibrium for the model outlined previously. (A more complete treatment of equilibrium can be found in Gale 2004.) We stress the market structure and its role in allowing economic agents to achieve an optimal allocation of risk and intertemporal consumption.

\section{Contingent Securities}

Aggregate uncertainty is determined by the four states of nature

$$
s \in S=\left[\left(\alpha_{H}, \beta_{H}\right),\left(\alpha_{L}, \beta_{H}\right),\left(\alpha_{H}, \beta_{L}\right),\left(\alpha_{L}, \beta_{L}\right)\right] .
$$

We denote these four states $H H, L H, H L, L L$. Contingent securities are defined by the date of delivery and the state on which delivery is contingent. The true aggregate state $s$ is unknown at date 0 and is revealed at date 1 , so there are nine contingent securities, a single contingent security which promises one unit of the good at date 0 and a contingent security that promises delivery of one unit of the good at date $t$ in state $s$ for every $t=1$, 2 and $s=S$. We denote the security delivering the good at date 0 by 0 and the security delivering the good at date $t$ in state $s$ by $(t, s)$ for $t=1,2$ and $s \in S$.

The simplest way to represent complete markets is to assume there exists a separate market at date 0 for each of the previously defined contingent securities. Take security 0 to be the numeraire and let $q_{t}(s)$ denote the price, in terms of the numeraire, of one unit of security $(t, s)$.

It is important to realize that the Arrow security markets only allow one to hedge aggregate risks. The idiosyncratic risks presented by the damage to individual firms insured by the insurance sector and the failure of individual firms borrowing from the banking sector cannot be hedged using 
these markets. However, because there are large numbers of firms in the respective sectors and the insurance companies and banks, respectively, can perfectly hedge these risks by pooling, markets for all risks, aggregate and idiosyncratic, are effectively complete once we take into account the role of the intermediaries as well as the Arrow securities. An alternative approach would have been to allow firms to enter markets for idiosyncratic risk. These markets would be competitive despite the presence of a single supplier, since the risks are effectively perfect substitutes in a world with perfect diversification.

\section{No-Arbitrage Conditions}

Because markets are complete, economic agents do not need to hold assets for the purpose of hedging risks or smoothing consumption. In fact, assets are redundant securities in the sense that they can be synthesized by trading contingent securities. Assets play an important role in equilibrium, however, because their existence places constraints on equilibrium prices and they are necessary to clear the goods market by altering the supply of contingent securities.

The short asset converts one unit of the good at date $t$ into one unit of the good at date $t+1$, independently of the state. Since the state is unknown at date 0 , the storage technology converts one unit of the good at date 0 into one unit of the good at date 1 , independently of the state. So investing one unit of the good in the storage technology at date 0 produces one unit of each of the contingent securities $(1, s)$ at date 1 . If the cost of the inputs is less than the value of the outputs, there is a riskless arbitrage, so equilibrium requires

$$
\sum_{s \in S} q_{1}(s) \leq 1 .
$$

At date 1 , the state is known, so it is possible to invest one unit in the short asset in state $s$ and produce one unit of the contingent security $(2, s)$ at date 2 . Then the no-arbitrage condition requires

$$
q_{2}(s) \leq q_{1}(s)
$$

for each state $s$. To see why this condition must hold, consider the following example, which violates the condition:

$$
q_{1}(s)=0.2<0.3=q_{2}(s) .
$$

A riskless arbitrage profit can be achieved as follows. At date 0 , buy one unit of the $(1, s)$ contingent security and sell one unit of the $(2, s)$ security for a profit of $0.3-0.2=0.1$. At date 1 , if state $s$ occurs, the $(1, s)$ contingent security yields one unit of the good. Investing this unit of the good in the short asset produces one unit of the good at date 2 in state $s$, which can be used to redeem the unit of the $(2, s)$ contingent security issued at date 0 . 
Investment in the long asset is only possible at date 0 , when the state is unknown, so the long asset only gives rise to one no-arbitrage condition. One unit of the good at date 0 yields $R$ units of the good at date 2 , independently of the state; in other words, $R$ units of the contingent security (2, $s$ ) for each state $s$. Then the no-arbitrage condition that the cost of the inputs is greater than or equal to the value of the outputs is

$$
\sum_{s \in S} q_{2}(s) R \leq 1
$$

These no-arbitrage conditions can also be thought of as zero-profit conditions. If the profit is negative, no one invests in the asset at that date and state; if someone does invest, the profit is zero. In either case, investments in the assets do not affect an economic agent's wealth (in the case of an individual) or market value (in the case of a firm). In the aggregate, some investment in these assets may be necessary in order to transform goods at one date into goods at a future date, but it is a matter of indifference which economic agent undertakes the investment activity. In particular, this implies a separation property that holds for every agent's decision problem: the optimal investment in the short and long asset is independent of the agent's optimal choice of other variables, such as consumption or loan and insurance contracts.

\section{Banking}

As in the standard Diamond and Dybvig (1983) model, banks provide liquidity insurance for consumers who are uncertain about the optimal timing of their consumption. Consumers deposit their endowments of one unit of the good with the bank at date 0 and are promised future consumption payments conditional on their types, early or late. An early consumer is promised $c_{1}(s)$ of the contingent security $(1, s)$ for each state $s$; a late consumer is promised $c_{2}(s)$ units of the contingent security $(2, s)$ for each state $s$. Thus, the contracts the banks offer are complete in the sense that they allow the payments made to vary across the aggregate states $s$. Free entry and competition in the banking sector force banks to offer contracts that maximize the expected utility of the typical depositor subject to the constraint that the bank break even on the deal. If a bank did not maximize the expected utility of depositors another bank would enter, offer a better contract and take away all its customers. The break-even condition is equivalent to a budget constraint that says that the value of promised consumption is less than or equal to the value of the deposits. The deposits are one unit per capita and the per capita demand for consumption is $\lambda c_{1}(s)$ at date 1 in state $s$ and $(1-\lambda) c_{2}(s)$ at date 2 in state $s$. The budget constraint can be written

$$
\sum_{s \in S}\left[q_{1}(s) \lambda c_{1}(s)+q_{2}(s)(1-\lambda) c_{2}(s)\right] \leq 1
$$


Recall that we can ignore the bank's investments since they yield zero profits. The expected utility of the typical depositor can be constructed as follows. In each state $s$, the depositor has a probability $\lambda$ of being an early consumer and $1-\lambda$ of being a late consumer, so his expected utility conditional on $s$ is $\lambda U\left[c_{1}(s)\right]+(1-\lambda) U\left[c_{2}(s)\right]$. Then the expected utility at date 0 , before the state is known, is obtained by taking expectations over states

$$
E\left\{\lambda U\left[c_{1}(s)\right]+(1-\lambda) U\left[c_{2}(s)\right]\right\} .
$$

It is important to note that the depositors cannot trade directly in the markets for contingent securities or assets. As Cone (1983) and Jacklin (1986) have shown, it is not possible for depositors to obtain liquidity insurance from a bank if they can directly trade the securities the banks hold.

In addition to providing consumption smoothing for consumers, the banks can invest in loans to firms. Because we assume that entrepreneurs with projects are in perfectly elastic supply and banks have access to a limited amount of deposits, equilibrium requires that entrepreneurs earn zero profits. In other words, all the surplus goes to the banks. Since one unit of the good at date 0 produces $B_{H}$ when the payoff is high and $B_{L}$ when the payoff is low, the zero-profit condition requires that the face value of a loan of one unit to the firm is $D=B_{H}$. In the high-payoff state the firm can repay the loan, but in the low payoff-state it defaults and the bank seizes the remaining value of the firm $B_{L}$. Because entrepreneurs are indifferent between borrowing to fund a project and not undertaking the project at all, the number of projects undertaken is determined by the supply of loanable funds from the bank. Although banks are earning a positive return on each loan, they are indifferent about the number of loans they offer because they can replicate these loans through the markets for Arrow securities (after pooling the idiosyncratic risks).

\section{Insurance}

Insurance companies provide two services to firms. Note that these firms are different from the firms that borrow from banks. The insurance companies insure the firm's assets against damage (if it is efficient to do so) and they provide consumption smoothing to the owner of the firm. We make this assumption for convenience, but it is not necessary. The firms could provide the same consumption-smoothing services for themselves by trading contingent securities. Recall that in order for banks to provide insurance to their depositors it was necessary to exclude the depositors from the asset markets. By contrast, there is no need to limit the market participation of the insurance companies' customers. Since the damage to assets is observed by the insurance companies, there is no incentive constraint to worry about. We will allow firms to participate in markets when we consider the case of incomplete markets in the sequel.

It is efficient to repair the damage to the firm's asset if the cost of doing 
so is less than or equal to the value of the asset's output; that is, if $q_{1}(s) C \leq$ $q_{2}(s) A$. An optimal insurance contract will make the decision to pay the damages contingent on the state. Contracts are again complete. The insurance company will also promise the firm owner consumption $a_{2}(s)$ at date 2 in state $s$. Free entry and competition in the insurance sector imply that the insurance companies offer firms a contract that maximizes the utility of the firm's owner subject to a break-even constraint. The break-even constraint is equivalent to the following budget constraint:

$$
\sum_{s \in S} q_{2}(s) a_{2}(s) \leq 1+\sum_{s \in S}\left\{\alpha(s) \max \left[q_{2}(s) A-q_{1}(s) C, 0\right]+[1-\alpha(s)] q_{2}(s) A\right\} .
$$

The left-hand side is the value of consumption promised to the owner; the right-hand side is the value of the owner's endowment at date 0 plus the value of outputs from the firm's assets at date 2 net of damage payments at date 1 . Note that we assume here that the insurance company can perfectly diversify across firms, so that exactly a fraction $\alpha(s)$ of its customers suffer damage in state $s$ and $1-\alpha(s)$ suffer no damage. Since the insurance companies are competitive, their objective is to maximize the firm owner's expected utility

$$
E\left\{U\left[a_{2}(s)\right]\right\},
$$

subject to the budget constraint above.

\section{Investors}

We can describe the investors' decision problem in a similar way, although it adds relatively little to our understanding of the model when markets are complete. Since there are a large number of investors with very large endowments, their consumption at date 0 is assumed to be positive. This implies that, unless they make zero profits by trading in markets for contingent securities, there will be an excess supply of investment. The only important implication for equilibrium takes the form of a no-arbitrage condition: any feasible consumption plan that requires the investor to sell $e_{0}$ units at date 0 and purchase $e_{t}(s) \geq 0$ units of the contingent security $(t$, $s)$ that increases expected utility must also cost a positive amount. Formally, if there exists a trade $\left(e_{0}, e_{t}[s]\right)$ such that

$$
E\left[e_{1}(s)+e_{2}(s)\right]>\rho e_{0},
$$

then it must be the case that

$$
\sum_{s \in S}\left[q_{1}(s) e_{1}(s)+q_{2}(s) e_{2}(s)\right]>e_{0} .
$$

Conversely, if $\left(e_{0}, e_{t}[s]\right)$ is a trade that occurs in equilibrium, then it must be the case that it leaves expected utility unchanged 


$$
E\left[e_{1}(s)+e_{2}(s)\right]=\rho e_{0},
$$

and it leaves the budget constraint unchanged.

$$
\sum_{s \in S}\left[q_{1}(s) e_{1}(s)+q_{2}(s) e_{2}(s)\right]=e_{0}
$$

Otherwise, the trade would violate the no-arbitrage condition. Again, the no-arbitrage condition constrains equilibrium prices but does not otherwise affect equilibrium.

Investors may share some of the risks born by consumers and firms, but they do so indirectly through the markets for contingent securities rather than through explicit risk-sharing contracts with individual consumers and firms. They perform this function by supplying $e_{0}$ at date 0 , which can be invested in short or long assets or can be used to finance loans by the banks, and then take their earnings in states where consumers and owners have a high marginal utility of consumption. By doing this, they allow consumers and owners to reduce the variation in their consumption across states.

\section{Welfare}

The first theorem of welfare economics tells us that, under very weak assumptions about nonsatiation, every equilibrium of an Arrow-Debreu economy has a Pareto-efficient allocation of goods and services. So in the equilibrium sketched previously, it is impossible to make some economic agents better off without making others worse off. In particular, risk sharing is efficient and there is no scope for government intervention or regulation to increase efficiency.

\section{Absence of Bank Runs, Bankruptcy, and Systemic Risk}

One important thing to note about the case of complete markets and contracts is that there is no bankruptcy for banks or insurance companies. Since it is possible to trade contingent securities for every state and contract payments can be varied in every state, assets and liabilities can always be matched so bank runs and bankruptcy do not occur. Since bank runs and bankruptcy do not occur there is no systemic risk with complete markets. As we will see, when markets and contracts are incomplete this is no longer the case, and this has important implications for the characteristics of equilibrium.

\subsubsection{The Modigliani-Miller Theorem for Risk Sharing}

In an Arrow-Debreu world, risk sharing is mediated by markets. In particular, the capital is provided to the market and not to any specific individual financial institution. Similarly, there are no over-the-counter (OTC) 
derivatives traded between banks and insurance companies. Instead, they trade contingent securities with "the market." One could introduce specific capital contracts between investors and banks or insurers, but these would be redundant securities. In fact, we can establish a Modigliani-Miller theorem for banks and insurers along the lines of Gale (2004). For example, suppose that a bank wants to raise an amount of capital $e_{0}$. It will offer investors a contract $\left(e_{0}, e_{1}, e_{2}\right)$ under which it promises to pay investors $e_{t}(s)$ in state $s$ at date $t$ in exchange for the contribution of $e_{0}$ at date 0 . In order to be acceptable to the investors, the capital contract $\left(e_{0}, e_{1}, e_{2}\right)$ will have to satisfy the participation constraint

$$
E\left[-\rho e_{0}+e_{1}(s)+e_{2}(s)\right] \geq 0 .
$$

The bank's objective function remains the same as before, but now the value of the capital contract is added to its budget constraint. Clearly, the bank will want to minimize the cost of the contract in order to maximize the market value of the bank. Thus, an optimal contract will minimize

$$
E\left[-e_{0}+q_{1}(s) e_{1}(s)+q_{2}(s) e_{2}(s)\right],
$$

subject to the participation constraint above. This problem is the dual of the investor's decision problem in the preceding section. Because of the linearity of the problem, in equilibrium the market value of the contract is zero and the participation constraint is binding. In other words, the capital contract will have no effect on the bank's budget constraint and no effect on its objective function. Furthermore, the introduction of an explicit capital structure has no effect on the endogenous variables we care about (the allocation of consumption and investment in assets) because the trades implied by the contract are offset in the contingent security markets.

In an exactly similar way, we can show that any insurance contract between banks and insurance companies would be redundant. This does not mean that risk is not being shared between the insurance and banking sectors. To the extent that there is any scope for sharing risk between the two sectors (credit risk transfer), it is exploited fully and efficiently, using the markets for contingent securities.

\subsubsection{Derivatives and Contracts}

In practice, we do not observe markets for contingent securities as such. Instead, we observe markets for spot trading of assets, a variety of derivative securities whose purpose is to allow hedging of risk from the underlying securities, and a variety of risk-sharing contracts such as insurance contracts. Regardless of the form that risk sharing takes, similarly to Ross (1976), if there are enough derivatives and contracts, markets will effectively be complete and the allocation of risk will be the same as in the Arrow-Debreu equilibrium. This is the sense in which credit risk transfer is 
desirable. If the instruments that transfer risk allow markets to be effectively complete, then they ensure a Pareto-efficient allocation of resources is achieved. This is the first main result of the paper-that credit risk transfer is desirable when markets and contracts are effectively complete.

This argument assumes there is no capital regulation and indeed this is optimal. What happens if there is capital regulation? Suppose next we get rid of all contingent securities so markets are no longer complete but allow a spot market for assets at date 1 (equivalent to a forward market for consumption at date 2). If we still allow banks and insurers to write complete contracts, then markets are effectively complete, because there are only two representative agents (plus the risk-neutral investors who receive no surplus). However, in this case, the net effect of risk sharing between investors and the banks or insurance companies must be mediated by an explicit contract, and it is this contract that is controlled by capital-adequacy regulation. If the bank is required to increase $e_{0}$, this will have a real impact on its feasible set and on the value of its objective function. It cannot be offset by side trades, because we assume that all trades are governed by pairwise contracts, and those between the investors and banks are explicitly regulated. Markets are no longer effectively complete and the properties of equilibrium change significantly.

We next develop a simple numerical example to show that, when markets and contracts are incomplete, there can be an increase in systemic risk as a result of capital regulation that forces banks to hold too much capital.

\subsection{Increased Systemic Risk from Capital Regulation}

In this section we present simple numerical examples to illustrate our second result - that capital regulation can increase systemic risk when markets and contracts are incomplete. In contrast to the previous section, we assume there are no state-contingent securities. Whereas with complete markets it was possible to trade securities that paid off 1 unit of the consumption good in aggregate states $H H, L H, H L$, and $L L$ at dates $t=1,2$, now this is not the case. There are only markets for the long and short assets. Contracts are also incomplete. Whereas before payoffs could be made explicitly contingent on states $H H, L H, H L$, and $L L$, this is no longer possible.

We start by considering the banking sector on its own and then go on to consider the insurance sector in isolation. Without capital regulation we show that in the example there is no incentive to have credit risk transfer between the two sectors. However, with capital regulation where capital can be reduced when there is credit risk transfer between the sectors, we show that the transfer will take place. Moreover, this credit risk transfer can increase systemic risk in the banking sector. 


\subsubsection{The Banking Sector}

\section{No Capital}

To start with we consider what happens if there is no capital available for banks from investors.

Example 1. The return on the long asset is $R=1.4$.

For depositors in the banks $\lambda=0.5$; and $U(c)=\operatorname{Ln}(c)$. In state $\beta_{H}$ for banks, which occurs with probability 0.7 , the loans pay off $B_{H}=1.7$ with probability $\beta_{H}=1$. The probability of state $\beta_{L}$ is 0.3 and in this state the loans pay off $B_{L}=0.9$ with probability $1-\beta_{L}=1$.

Banks' investment in the short asset is denoted $x$, their investment in the long asset is denoted $y$, and their loans to firms are denoted $z$. They receive an endowment of 1 from depositors, so $x+y+z=1$.

The contract the banks use with their depositors are incomplete in the following sense. The banks cannot make the payment at date 1 contingent on the aggregate state. The aggregate state at date 1 is now observable but not verifiable, and hence contracts cannot be made contingent on it. Instead, the deposit contract banks use promises a fixed amount $c_{1}$ to any depositor wishing to withdraw. Since the banking industry is competitive, then as before each bank's objective is to maximize the expected utility of its depositors. If a bank did not do this then another bank would enter, offer a better contract, and take away all its customers. The implication of this is that the banks will pay out all their remaining funds to late consumers at date 2 . The amount the late consumers will receive will depend on whether firms' loans are repaid in full. Hence there are two possible payouts, $c_{2 H}$ in state $\beta_{H}$, and $c_{2 L}$ in state $\beta_{L}$.

Banks are unable to distinguish between early and late consumers. If late consumers deduce that they will be better off withdrawing at date 1 then all depositors will attempt to withdraw. If a bank is unable to meet the demands of its depositors then it goes bankrupt, its assets are liquidated, and the proceeds are distributed to the depositors in proportion to their deposits. When markets and contracts were complete, assets and liabilities could be balanced state by state and bankruptcy never occurred. Now, however, bankruptcy may occur if late consumers have an incentive to pretend to be early consumers, so there is a run on the bank.

At date 0 , the banks choose their portfolio, $x, y$, and $z$, and the deposit contract $c_{1}, c_{2 H}$, and $c_{2 L}$, to maximize the expected utility of the depositors. In equilibrium, $x, y$, and $z$ must be nonnegative. We will suppose initially that there are no runs and check to see that this assumption is satisfied. Since in this case there is no uncertainty about the banks' needs for liquidity at date 1 , they will use the short-term asset to provide consump- 
tion at date 1 . The optimization problem of the banks is to choose $x, y$, and $z$ to

$$
\begin{aligned}
& \operatorname{Max} 0.5 U\left(c_{1}\right)+ 0.5\left[0.7 U\left(c_{2 H}\right)+0.3 U\left(c_{2 L}\right)\right] \\
& \text { subject to } x+y+z=1, \\
& c_{1}=\frac{x}{0.5} \\
& c_{2 H}=\frac{y R+z B_{H}}{0.5}, \\
& c_{2 L}=\frac{y R+z B_{L}}{0.5} .
\end{aligned}
$$

The first constraint is the budget constraint at date 0 . The second constraint gives the per capita consumption of the early consumers. Since there is 1 depositor and 0.5 of these are early consumers and 0.5 are late consumers, we need to divide the total consumption produced by the investment in the short asset at date 1 by 0.5 to get the per capita consumption. The third and fourth constraints give the per capita consumption of the late consumers in states $\beta_{H}$ and $\beta_{L}$ respectively. Clearly, $c_{2 H} \geq c_{2 L}$. In order for a run to be avoided, we also need $c_{2 L} \geq c_{1}$; otherwise, late consumers will pretend to be early consumers and will withdraw their money at date 1 .

Denoting the Lagrange multiplier for the constraint $\mu$, the first order conditions are:

$$
\begin{gathered}
\frac{0.5}{x}-\mu \leq 0, \\
\frac{0.35 R}{y R+z B_{H}}+\frac{0.15 R}{y R+z B_{L}}-\mu \leq 0, \\
\frac{0.35 B_{H}}{y R+z B_{H}}+\frac{0.15 B_{L}}{y R+z B_{L}}-\mu \leq 0 .
\end{gathered}
$$

The solution for the equilibrium is

$$
\begin{gathered}
x=0.5 ; y=0.22 ; z=0.28 \\
c_{1}=1 ; c_{2 H}=1.568 ; c_{2 L}=1.12 \\
E U=0.1744
\end{gathered}
$$

It can be seen directly that $c_{2 L}>c_{1}$, so in state $\beta_{L}$ late consumers will not have an incentive to withdraw their money and cause a run. As a result there will be no systemic risk in the banking industry. 


\section{The Role of Capital}

Next consider what happens if there are investors who can make capital available to the banks.

For the investors providing equity capital, the opportunity $\operatorname{cost}$ is $\rho=1.5$.

Since the investors are indifferent between consumption at date 1 and date 2 , it is optimal to set $e_{1}=0$ and not invest any of the capital $e_{0}$ that is contributed at date 0 in the short asset. In state $\beta_{H}$, when depositors' marginal utility of consumption is the lowest, it is possible to make a payout $e_{2}$ to investors. The banks' optimization problem is the same as before except now the date 0 budget constraint is

$$
x+y+z+e_{0}=1 .
$$

and

$$
c_{2 H}=\frac{y R+z B_{H}-e_{2}}{0.5} .
$$

In order for the investors to be willing to supply the capital $e_{0}$ it is necessary that

$$
e_{0} \rho=0.7 e_{2}
$$

so

$$
c_{2 H}=\frac{y R+z B_{H}-e_{0} \rho / 0.7}{0.5} .
$$

The first-order conditions for $x, y, z$, and $e_{0}$ are now

$$
\begin{gathered}
\frac{0.5}{x}-\mu \leq 0, \\
\frac{0.35 R}{y R+z B_{H}-e_{0} \rho / 0.7}+\frac{0.15 R}{y R+z B_{L}}-\mu \leq 0, \\
\frac{0.35 B_{H}}{y R+z B_{H}-e_{0} \rho / 0.7}+\frac{0.15 B_{L}}{y R+z B_{L}}-\mu \leq 0, \\
-\frac{0.35 \rho / 0.7}{y R+z B_{H}-e_{0} \rho / 0.7}+\mu \leq 0 .
\end{gathered}
$$

The solution for the equilibrium in this case is

$$
\begin{gathered}
x=0.5 ; y=0 ; z=0.726 ; e_{0}=0.226 \\
c_{1}=1 ; c_{2 H}=1.5 ; c_{2 L}=1.306 \\
E U=0.1820
\end{gathered}
$$


Once again there is no danger of runs and hence no systemic risk, since $c_{2 L}>c_{1}$.

Comparing the case without capital to the case with, it can be seen that expected utility is increased from 0.174 to 0.182 . Capital allows the depositors to share risk with the investors. This improves welfare directly but it also allows the bank to invest more in loans and less in the long asset, which has a lower expected return (1.40) than the loans (1.46). This increases expected consumption for the late consumers from $0.7 \times 1.568+0.3 \times 1.12$ $=1.434$ to $0.7 \times 1.5+0.3 \times 1.306=1.442$. In addition to this increase in expected consumption there is also clearly a reduction in the variability of consumption ( 1.568 and 1.12 before versus 1.5 and 1.306 now), because the repayment to investors occurs only in the good state. Risk is not eliminated from the depositors' consumption even though the investors providing the capital are risk neutral because capital is costly. The investors' opportunity cost of capital is $\rho=1.5$ while the expected return on the loans is only 1.46 and on the long asset 1.4. It is only the increase in expected utility from smoothing consumption that makes it worthwhile using investors' capital, and only up to the point where the marginal benefit is equal to the marginal cost. This is why depositors continue to bear risk.

This is not the only kind of situation that can occur. In some cases the bank will not want to use capital at all. To see this consider the following example.

Example 2. This is exactly the same as Example 1 except that $R=1.28, B_{H}$ $=1.6$, and $B_{L}=0.8$, so $E B=1.36$.

It can be shown that the equilibrium - whether capital is available or not-is the same.

$$
\begin{gathered}
x=0.5 ; y=0.333 ; z=0.314 ; e_{0}=0 \\
c_{1}=0.990 ; c_{2 H}=1.494 ; c_{2 L}=0.990 \\
E U=0.1341
\end{gathered}
$$

There is no role for capital at all in this example. Any capital regulation that imposes a positive minimum requirement will lead to inefficiency.

We will use Example 2 when we consider the banking and insurance sectors together.

\subsubsection{The Insurance Sector}

We next turn to the insurance sector and consider it on its own. As explained earlier there are firms that own assets that produce $A$ at $t=2$ if they are undamaged. For our example, we assume that $A=1.3$. The owners of these firms consume at date 2 and have $U=\operatorname{Ln}(c)$.

With some probability $\alpha(s)$ a firm's asset is damaged at date $t=1$. It costs 
$C=0.8$ to repair the asset, in which case it produces $A$ at $t=2$. Without repair the asset produces nothing. Insurance companies insure the firms and allow the risk to be pooled. As before, the firms that the insurance companies insure are different from the firms that the banks make loans to.

The parameters for Example 2 are used, so $R=1.28$.

State $\alpha_{H}$ occurs with probability 0.9 , and in this case $\alpha_{H}=0.5$ firms have damaged machines. State $\alpha_{L}$ occurs with probability 0.1 and $\alpha_{L}=1$ firms have damaged machines.

Similarly to the banking sector, the insurance companies cannot access complete markets with securities contingent on aggregate states. They can only buy the long and short assets. They also cannot write state-contingent contracts. They can promise to insure the firms' machines irrespective of state $s$. This means that an insurance company may go bankrupt. In this case its assets are liquidated and distributed to the firms it was insuring.

The costs of an insurance company liquidating long-term assets at date $t=1$ if it goes bankrupt is such that the proceeds are zero. Grace, Klein, and Phillips (2003) have found that for a large sample of insurers that went bankrupt from 1986-1999 the average cost of insolvent firms accessing the guarantee funds was $\$ 1.10$ per $\$ 1$ of preinsolvency assets. By way of contrast, James (1991) found that the figure for banks for the late 1980s was $\$ 0.30$.

Each firm has an endowment of 0.8 at date $t=0$ that it can use to buy insurance or invest itself. As mentioned in the previous section, it will be assumed that the firms just buy insurance from the insurance companies. The firms can use the markets for the long and the short assets to smooth consumption for their owners.

\section{No Capital}

The insurance industry is competitive, so the companies do not earn any profits-all funds are paid out to the firms they insure. At date 0 the insurance companies' objective is to maximize the expected utility of the firms' owners. If they did not do this another insurance company would enter and take their business away. The insurance companies can offer partial or full insurance to firms. If they offer partial insurance they charge $0.5 C$ $=0.4$ at date $t=0$. Suppose the firms put the other 0.4 of their endowment in the long-term asset (it will be shown that this is optimal shortly). In order to have funds to allow firms' damaged assets to be repaired, the insurance companies must invest in the short asset so that they have liquidity at date $t=1$. In state $\alpha_{H}$, the funds they need for claims to repair the damaged assets are $\alpha_{H} C=0.4$. They have funds of 0.4 and can pay all the claims to repair the damaged assets. The amount the owners of the firms obtain is therefore $A+0.4 R=1.812$. In state $\alpha_{L}$, the insurance companies receive claims of $\alpha_{L} C=0.8$. They don't have sufficient funds to pay these so they 
go bankrupt. With partial insurance there is thus systemic risk in the insurance industry. When the insurance companies go bankrupt their assets are distributed equally among the claimants. The firms receive 0.4 from the insurance companies' liquidation of its short term assets. The firms can't repair their assets so these produce nothing. In state $\alpha_{L}$, the amount the owners of the firm receive is therefore $0.4+0.4 R=0.912$. Their expected utility with partial insurance is

$$
E U_{\text {partial }}=0.9 U(A+0.4 R)+0.1 U(0.4+0.4 R)=0.5258 .
$$

If the insurance company offered full insurance they would charge 0.8 at $t=0$ and could meet all of their claims in both states. At $t=1$ in state $\alpha_{H}$ they would have 0.4 left over. Since the industry is competitive, they would pay this out to the insured firms. In this case

$$
E U_{\text {full }}=0.9 U(A-0.4)+0.1 U(A)=0.5038 .
$$

This is worse than partial insurance.

If the firms decide not to have insurance then they would invest their endowment in the long asset. Their expected utility would be

$$
E U_{\text {none }}=0.9[0.5 U(0.8 R)+0.5 U(A+0.8 R)]+0.1 U(0.8 R)=0.3925 .
$$

Finally, if they decided to self-insure and hold their endowment in the short asset so they could repair their machines when necessary they would obtain

$$
E U_{\text {self }}=0.9[0.5 U(A)+0.5 U(A+0.8)]+0.1 U(A)=0.4782 .
$$

Thus the optimal scheme is for the insurance industry to partially insure firms and to charge 0.4 at $t=0$. The firms put the remaining part of their endowment in the long asset.

\section{The Role of Capital}

In this case there is no role for capital in the insurance sector. Capital providers charge a premium. Their funds would have to be invested in the short asset. There are already potentially enough funds from customers to do this, but it is simply not worth it. If there is a premium to be paid for the capital it is even less worth it. Capital will not be used in the insurance industry if it is not regulated to do so.

\subsubsection{Bringing Together the Banking and Insurance Sectors}

Now consider what happens if we consider the two sectors together and look at possible interactions. We start with the situation where there is no regulation and then go on to consider what happens with regulation. 


\section{No Regulation}

Without any regulation both sectors have the same equilibrium as when they are considered on their own. Given that markets and contracts are incomplete, there are no incentives for the insurance sector to insure the banking sector and have credit risk transfer. All the insurance sector could do is to hold the long-term asset and pay off when the loans default. But the banking sector can do this on its own. In fact, with insurance the systemic risk means that there would be a strict loss in this case. The value of the long-term assets held in the insurance companies would be lost.

There is also no gain for the banking sector to bear the risk of the insurance sector. They would have to hold the short-term asset, but the insurance sector can do this just as efficiently.

Of course, if markets and contracts were complete then there would be an incentive to share risk. The consumption at date 2 of the bank depositors and insured firms' owners are as follows.

\begin{tabular}{lcccc}
\hline & \multicolumn{4}{c}{ State } \\
\cline { 2 - 5 } & $H H$ & $L H$ & $H L$ & $L L$ \\
\hline Bank depositors & 1.494 & 1.494 & 0.990 & 0.990 \\
Insured firm owners & 1.812 & 0.912 & 1.812 & 0.912 \\
\hline
\end{tabular}

By, for example, transferring consumption from the bank depositors to the insured firms' owners in state $L H$ in the amount of 0.0386 and vice versa in state $H L$ in the amount of 0.01 it is possible to make both groups better off. If the shocks to the two sectors are independent then the expected value of this transfer is

$$
0.07 \times 0.0386-0.27 \times 0.01=0 .
$$

The expected utility of the bank depositors is improved from 0.1341 to 0.1394 and the expected utility of the insured firms' owners goes from 0.5258 to 0.5272 . With complete markets and contracts optimal risk sharing would ensure that the ratios of marginal utilities of consumption of the bank depositors and the owners of the insured firms across states would be equated. This is clearly far from being the case here. The incomplete markets and contracts that are actually in place in this section prevent improved risk sharing of this type, and in fact there is no possibility of an improvement through credit risk transfer in the absence of capital regulation.

\section{Equilibrium with Inefficient Capital Regulation in the Banking Sector}

Now suppose that the government requires banks to have a certain minimum amount of capital. There is no role for capital regulation in our 
model, so it can have no benefit. It may be harmless if the required level is below the optimal level. The more interesting case is when it is set at too high a level.

Suppose in Example 2 that the government requires banks to have $e_{0}=$ 0.2 compared to the optimal level of 0 . The solution to the banks' problem then becomes

$$
\begin{gathered}
e_{0}=0.2 ; e_{1}=0 ; e_{2}=0.429 ; \\
x=0.494 ; y=0 ; z=0.706 \\
c_{1}=0.988 ; c_{2 H}=1.401 ; c_{2 L}=1.129 \\
E U=0.1305
\end{gathered}
$$

The capital improves risk sharing and allows more funds to be invested in loans, both from the extra capital and from the lower-return long asset. However, the high cost of capital means that this is inefficient; welfare is reduced from the case with no regulation.

\section{Inefficient Capital Regulation in Banking and Credit Risk Transfer to the Insurance Sector}

Next, consider what happens if we allow for the possibility of credit risk transfer from the banking sector to the insurance sector. It is supposed that the shocks to the two sectors are independent. The regulation is such that the existence of hedging of credit risk allows a reduction in the capital requirement. By purchasing an insurance contract with cost of $G=0.02$ at date 0 and a payoff of $0.02 \times R=0.026$ at date 2 when loans do not pay off it is possible for a bank to reduce its capital requirement to the optimal level of 0 . The idea here is that the regulation does not work effectively, since under Basel II banks can use their own risk models. They can therefore construct their risk models to make it look as if the hedging instrument reduces risk the right amount so as to allow them to reduce capital to the optimal level. Notice that in order for this insurance contract to be such that the insurance companies break even, which is necessary because of competition, they will also provide a payment of 0.026 when the loans do pay off, if they are able to. The insurance companies use the initial payment from the banks at date 0 to buy the long-term asset and then pay out the proceeds when they are solvent. When they are not solvent the long-term asset is wasted because of the inefficient liquidation in the insurance sector. The only point of the credit risk transfer is to arbitrage the inefficient capital regulation in the banking sector. The key issue is whether the gain from this inefficient risk transfer outweighs the inefficiency of the capital regulation. It can be shown that in the example it does. The bank chooses its portfolio $x, y$, and $z$ to maximize the depositors' expected utility, taking $G=0.02$ and $e_{0}=0$ as given. 


$$
\begin{aligned}
\operatorname{Max} E U=0.5 U\left(c_{1}\right)+ & 0.5\left\{0.7\left[0.9 U\left(c_{2 H H}\right)+0.1 U\left(c_{2 L H}\right)\right]\right. \\
& \left.+0.3\left[0.9 U\left(c_{2 H L}\right)+0.1 U\left(c_{2 L L}\right)\right]\right\} \\
\text { subject to } 1+e_{0}=x+y+z+G . & \\
c_{1}= & \frac{x}{0.5}, \\
c_{2 H H}= & \frac{y R+z B_{H}-e_{0} \rho / 0.7+G R}{0.5}, \\
c_{2 L H}= & \frac{y R+z B_{H}-e_{0} \rho / 0.7}{0.5}, \\
c_{2 H L}= & \frac{y R+z B_{L}+G R}{0.5}, \\
c_{2 L L}= & \frac{y R+z B_{L}}{0.5} .
\end{aligned}
$$

Solving this gives the following:

$$
\begin{gathered}
x=0.5 ; y=0.15 ; z=0.33 ; e_{0}=0 \\
c_{1}=1 ; c_{2 H H}=1.491 ; c_{2 L H}=1.440 ; c_{2 H L}=0.963 ; c_{2 L L}=0.912 \\
E U=0.1322
\end{gathered}
$$

So the expected utility of the banks' depositors is improved relative to the case with no credit risk transfer $(E U=0.1305)$ but, of course, they are not as well off as in the case with no regulation $(E U=0.1341)$, because the credit risk transfer has costs associated with it. However, all this is beside the point, because the solution assumes there will be no runs-but in fact there will be runs in states $H L$ and $L L$. In state $H L, c_{2 H L}=0.963<c_{1}=1$, and in state $L L, c_{2 L L}=0.912<c_{1}=1$. In both cases the late consumers as well as the early consumers will attempt to withdraw their funds. The banks will anticipate this and will optimize taking this into account.

A key issue is what happens if there is a run on the bank in terms of the liquidation value of the long asset and loans it holds. For simplicity, we assume the bank can liquidate its assets for their full value. As mentioned previously, James (1991) found that the cost of liquidating bank assets in the late 1980 s was $\$ 0.30$ per dollar of assets, which is much lower than the $\$ 1.10$ per dollar cost of liquidating insurance assets that Grace, Klein, and Phillips (2003) found. We could allow for some small loss of asset value and all of these results would hold. The more inefficient the banking regulation, the greater this loss can be. 
In the optimal solution, taking into account bankruptcy, the banks go bankrupt in state $L L$ and both the early and late consumers receive the same amount

$$
c_{1 L L}=c_{2 L L}=x+y R+z B_{L} .
$$

The full solution is

$$
x=0.492 ; y=0.188 ; z=0.300 ; e_{0}=0
$$

In states $H H, L H$, and $H L$ the banks avoid bankruptcy:

$$
c_{1}=0.984 ; c_{2 H H}=1.493 ; c_{2 L H}=1.441 ; c_{2 H L}=1.012
$$

In state $L L$ the banks go bankrupt:

$$
\begin{gathered}
c_{1 L L}=c_{2 L L}=0.973 \\
E U=0.1318
\end{gathered}
$$

We have thus shown the second result of the paper, namely that with inefficient banking regulation credit risk transfer can increase overall systemic risk. The insurance industry is hit by a large shock when it has high claims from the firms it insures. At the same time, the banking industry has low returns on its loans. Whereas without credit risk transfer the banks avoided bankruptcy, this is not optimal any longer. They go bankrupt and there is contagion from the insurance industry to the banking industry. The credit risk transfer has created links between the industries and this allows contagion.

\subsection{Concluding Remarks}

In this paper we have developed a model of a financial system with both banking and insurance sectors. Banks and insurance companies do different things. Banks provide liquidity insurance to depositors, whereas insurance companies pool risks. The first result was to show that with complete markets and contracts for aggregate risks intersectoral transfers are desirable. They allow risk to be shared efficiently between the different industries. The second result was to show that with incomplete markets and contracts for aggregate risks credit risk transfer can occur as the result of regulatory arbitrage and this can increase overall systemic risk.

The key question going forward, of course, is which view of credit risk transfer is empirically relevant. As documented in section 7.2, the amount of credit risk transfer between the two industries is currently relatively small. Even if one were to take the view that this credit risk transfer is the result of regulatory arbitrage then the systemic risk may be slight. However, going forward, transfers between sectors may increase, and if they are the result of regulatory arbitrage, they may lead to an increase in systemic risk. 
Perhaps more importantly, although the model can be interpreted literally as being about banking and insurance, it can also be viewed more generally. The other group of institutions that in recent years has been playing an increasingly important role in the transfer of credit and the repackaging of risk in general has been hedge funds (BIS 2005). If markets function well in the sense that risk-sharing opportunities are complete, then these transfers of risk around the economy are desirable. However, if they are the result of inefficient regulation and regulatory arbitrage, they may not be. Since hedge funds are unregulated while a large part of the financial services industry is regulated, much of this activity may well be the result of regulatory arbitrage. More empirical work analyzing the nature of risk reallocation in the economy is required to understand the full consequences on systemic risk.

In the model presented, systemic risk was not particularly damaging. Assets could be liquidated in the banking system for the full amount of their value. In practice, systemic risk can be extremely damaging. Augmenting the model to allow for endogenous liquidation values and spillovers to the real economy means that the kind of effect modeled here with incomplete markets may be quite damaging.

\section{References}

Allen, F., and D. Gale. 1998. Optimal financial crises. Journal of Finance 53:1245-84. 2000a. Comparing financial systems. Cambridge, MA: MIT Press. 2000b. Financial contagion. Journal of Political Economy 108:1-33.

2000c. Optimal currency crises. Carnegie-Rochester Conference Series on Public Policy 53:177-230.

2003. Capital adequacy regulation: In search of a rationale. In Economics for an imperfect world: Essays in honor of Joseph Stiglitz, ed. R. Arnott, B. Greenwald, R. Kanbur, and B. Nalebuff, 83-109. Cambridge, MA: MIT Press.

- 2004a. Financial fragility, liquidity, and asset prices. Journal of the European Economic Association 2:1015-48.

. 2004b. Financial intermediaries and markets. Econometrica 72:1023-61.

British Bankers Association (BBA). 2002. Credit Derivatives Report. London: British Bankers Association.

Bank for International Settlements (BIS). 2003. Committee on the Global Financial System. Credit Risk Transfer. Basel, Switzerland: Bank for International Settlements.

- 2005. Basel Committee on Banking Supevision. Credit Risk Transfer. Basel, Switzerland: Bank for International Settlements.

Chiesa, G. 2004. Risk transfer, lending capacity and real investment activity. Working paper, Department of Economics, University of Bologna.

Cone, K. 1983. Regulation of depository institutions. PhD diss., Stanford University.

Diamond, D., and P. Dybvig. 1983. Bank runs, deposit insurance, and liquidity. Journal of Political Economy 91:401-19. 
Fitch Ratings. 2003. Global credit derivatives: Risk management or risk? Retrieved March 10, 2003. www.fitchratings.com.

Gale, D. 2003. Financial regulation in a changing environment. In Framing financial structure in an information environment, ed. T. Courchene and E. Neave, 1536. Kingston, Ontario: John Deutsch Institute for the Study of Economic Policy, Queen's University.

2004. Notes on optimal capital regulation. In The evolving financial system and public policy, ed. P. St-Amant and C. Wilkins, 225-53. Ottawa: Bank of Canada.

Gale, D., and O. Özgür. 2005. Are bank capital ratios too high or too low: Risk aversion, incomplete markets, and optimal capital structures. Journal of the European Economic Association 3:690-700.

Grace, M., R. Klein, and R. Phillips. 2003. Insurance company failures: Why do they cost so much? Working paper, Georgia State University, Department of Management and Insurance.

Hellwig, M. 1994. Liquidity provision, banking, and the allocation of interest rate risk. European Economic Review 38:1363-89.

. 1995. Systemic aspects of risk management in banking and finance. Schweizerische Zeitschrift für Volkswirtschaft und Statistik 131:723-37.

- 1998. Banks, markets, and the allocation of risks. Journal of Institutional and Theoretical Economics 154:328-51.

Jacklin, C. 1986. Demand deposits, trading restrictions, and risk sharing. In Contractual arrangements for intertemporal trade, ed. E. Prescott and N. Wallace, 2647. Minneapolis: University of Minnesota Press.

James, C. 1991. The losses realized in bank failures. Journal of Finance 46:1223-42.

Morrison, A. 2005. Credit derivatives, disintermediation and investment decisions. Journal of Business 78:621-47.

Nicolo, A., and L. Pelizzon. 2004. Credit derivatives: Capital requirements and strategic contracting. Working paper, Department of Economics, University of Padua.

Ross, S. 1976. Options and efficiency. Quarterly Journal of Economics 90:75-89.

Wagner, W. 2005a. Interbank diversification, liquidity shortages and banking crises. Working paper. Cambridge Endowment for Research in Finance, University of Cambridge.

. 2005b. The liquidity of bank assets and banking stability. Working paper. Cambridge Endowment for Research in Finance, University of Cambridge.

Wagner, W., and I. Marsh. 2004. Credit risk transfer and financial sector stability. Working paper. Cambridge Endowment for Research in Finance, University of Cambridge.

\section{Comment Charles W. Calomiris}

The Allen-Gale paper is motivated in part by the observation that substantial credit risk has been transferred from bank portfolios to insurance company portfolios in recent years through credit risk derivatives. The authors ask whether this risk transfer reflects, in part, a form of regulatory capital arbitrage, as risk migrates toward a more favorable (lenient) set of risk-based regulatory capital requirements for insurance companies. Their 
model shows that, under those circumstances, such a risk transfer can have the undesirable effect of making the financial system as a whole more fragile by reducing the amount of capital relative to risk for the financial system as a whole.

In a recent study, Minton, Stulz, and Williamson (2005) quantified the use of credit risk derivatives and found that, as of 2003, only nineteen of 345 large U.S. bank holding companies in their sample actually use credit derivatives, but the assets of these nineteen bank holding companies account for roughly two-thirds of total bank holding company assets. They also find that banks that are more likely to buy protection in the credit derivatives market are also more likely to be asset securitizers, and that those banks also tend to have low capital ratios. Those facts provide some evidence that at least is consistent with the notion that regulatory capital arbitrage could be a factor in bank decisions to use credit derivatives to hedge loans.

But there are reasons to think that (a) regulatory capital arbitrage may not be all bad, and (b) minimum regulatory capital requirements for insurance companies or banks may not be binding constraints on the amount of capital that is allocated to absorb default risk. With respect to the possible desirability of regulatory capital arbitrage, it is important to remember that it is possible for regulatory requirements to be set too high as well as too low. Suppose that, absent any regulatory limits, and based solely on the preferences of market participants (including the stockholders and debtholders of banks and insurance companies), the equilibrium capital ratios of banks would be lower than the minimum regulatory requirements set by regulators. In that case, it is possible that regulatory capital arbitrage can be socially beneficial, since it allows the financial system to make full use of scarce equity capital. That is particularly true if private market discipline substitutes for regulatory discipline by ensuring that capital is maintained by arbitraging financial institutions so that its quantity varies positively with asset risk.

Calomiris and Mason (2004) make precisely these arguments about credit card-securitizing banks. While they recognize that an important part of the motivation for credit card securitization is regulatory capital arbitrage, they conclude that credit card issuers choose equilibrium capital ratios above the regulatory minimum that those institutions could have chosen. They interpret that evidence as suggesting that market discipline is the binding constraint determining the capital requirements for card issuers (relative to total, on- and off-balance sheet risk). Furthermore, Calomiris and Mason (2004) argue that part of the reason that regulators, ratings agencies, and market participants may permit arbitrage, as well as some other questionable accounting practices that securitization entails, is that they recognize that the one-size-fits-all, "risk-based" capital standard applied to banks probably results in a disproportionately large ratio of 
bank capital relative to risk (compared to other banks) for credit card banks that would keep credit card receivables entirely on their balance sheets. Thus, in the case of credit card receivables, it may be that markets, not regulators, are constraining capital-risk choices of banks, and that regulatory capital arbitrage makes financial intermediation more efficient by avoiding the waste of idle equity capital.

With respect to credit risk derivatives, the analogous question is whether insurance companies face market discipline that constrains their choices of risk in ways that limit the systemic vulnerability that Allen and Gale posit. Surely, policyholders in insurance companies, or guaranteed investment contract (GIC) holders, wish to avoid loss, and to the extent that they are not perfectly protected by governments, might react to unwarranted choices of risk relative to capital by moving their business to other insurance companies. Indeed, there is a substantial body of evidence suggesting that market discipline can constrain the risk choices of financial institutions, including banks and insurance companies, so long as they are not protected too much from market discipline by the government safety net (Brewer, Mondschean, and Strahan 1992, Brewer and Mondschean 1993, Calomiris and Powell 2001, Calomiris and Mason 2003, Calomiris and Wilson 2004, Barth, Caprio, and Levine 2004).

Indeed, in historical banking systems that lacked both deposit insurance and minimum capital ratio requirements (the former having been created in the United States in 1934, the latter dating from the 1980s), bank capital ratios tended to be higher than for today's banks. The same is true for uninsured financial institutions today. For example, finance companies, which rely primarily on very short-term commercial paper for their funding, maintain capital ratios that vary positively with their asset risk (Calomiris and Mason 1998). Calomiris and Mason also show that, as of 1996, book equity capital relative to assets differed substantially across types of financial intermediaries, and that, on average, categories of intermediaries with higher asset risk (measured by the standard deviation of asset returns, inferred from equity returns and leverage ratios) maintained higher book equity capital, as shown in table 7C.1.

Thus, from the perspective of the literature on the market discipline of financial institutions, regulatory capital arbitrage, per se, may not pose a significant systemic risk; rather, the greater threat to systemic risk likely comes from the joint imposition of government protection and government prudential regulation and supervision (including the setting and enforcing of capital ratios) in ways that remove market incentives to limit bank risk and maintain adequate capital. Part of that risk relates to the failure of regulators to properly set minimum risk-based capital requirements; part of that systemic risk relates to the failure of supervisors to enforce regulatory limits that have been set (e.g., by properly accounting for bank losses). In short, it may be that regulatory arbitrage is mainly a problem in the finan- 
Equity ratios and asset risks for various financial intermediaries

\begin{tabular}{lrcc}
\hline & $N$ & BE/A & Sigma of assets \\
\hline Bank holding companies & 378 & 0.09138 & 0.25553 \\
Investment banks & 55 & 0.29358 & 0.91031 \\
Life insurance companies & 51 & 0.12796 & 0.27275 \\
Property and casualty & 108 & 0.28110 & 0.52845 \\
Finance companies & 95 & 0.25442 & 0.96147 \\
\hline
\end{tabular}

Source: Calomiris and Mason (1998).

Note: $\mathrm{BE} / \mathrm{A}=$ book equity/assets.

cial system when government puts itself in charge of managing risk by removing any private incentive to do so, and then fails to provide an adequate regulatory substitute for private market discipline.

Of course, that is not the end of the story. There is no guarantee, even in a well-functioning financial system with private market discipline, that the aggregate amount of capital chosen by financial institutions will be the socially optimal level. Liquidity crises, after all, probably entail significant economic externalities. The loss of bank capital in the aggregate can prevent the financial system from maintaining its proper role in providing new credit to the nonfinancial sector, resulting in endogenous declines in asset prices, bank loan quality, and macroeconomic activity, which feed on one another. Externalities arise because the failure of one firm, sector, or intermediary can have consequences for others. For example, in the fall of 1998, Russia's financial collapse put pressure on global hedge funds to cut their risks in order to maintain low default probabilities on their debts, in the wake of losses from their Russian positions. Other emerging market securities that trade in international markets declined in price, putting pressure on many other financial institutions and issuers that had no direct connection to Russia's problems.

It would be desirable to construct a realistic model that would capture such effects and help us to gauge whether macroeconomic externalities are large enough to motivate minimum capital requirements in excess of the privately chosen optimum. Such a model should consider how private market discipline works (that is, solve for the privately determined risk-based capital ratios of intermediaries in the absence of regulation), and should model the causal links from an initial loss of capital to a subsequent contraction of credit supply by banks seeking to meet private market discipline, which would entail further declines in firms' asset values, leading in turn to further loan losses for banks and further market discipline (see, for example, Von Peter 2004). And such a model should also recognize the social costs of raising capital requirements (since equity capital is costly to raise, and a scarcity of equity capital can limit the supply of credit).

Many models of banking, including the one in this chapter, are not likely 
to get us very far toward addressing the question of whether, and by how much, externalities motivate higher capital requirements. Allen and Gale's model conceives of banks as a consumption inventory technology (i.e., following the Diamond and Dybvig 1983 model), not a risk-control/creditsupply technology. We are not going to get very far down the road toward modeling macroeconomic externalities and capital requirements for banks without considering (1) how private market discipline would constrain capital and risk choices in the absence of capital requirements, (2) how costly it is to raise equity capital, (3) how those costs of raising capital vary over the business cycle, or (4) how to model dynamic linkages among bank credit, asset prices, loan quality, and bank capital ratios.

If it could be shown that macroeconomic externalities motivate an increase in minimum capital requirements, the next step would be to ask how those capital requirements (in excess of what is demanded by the market) might be credibly enforced. Experience has taught that one cannot simply take for granted that such requirements will be enforced, since the rule throughout the world has been that enforcement is lax when it is most needed. Much recent work has argued that market signals could be harnessed by regulators to improve the credible enforcement of capital requirements, and this seems to be a promising approach, especially for constraining supervisory and regulatory forbearance (see, for example, Shadow Financial Regulatory Committee 2000, Calomiris and Powell 2001). The current regulatory approach favored by the Group of Seven (G7), however, is quite different, relying on complex formulas constructed by regulators, and internal bank risk modeling subject to regulatory scrutiny. That approach may work, but it has not been tested yet and I am very skeptical. The biggest problem of capital standards enforcement is the tendency of supervisors and regulators to relax standards when times get rough. Complex formulas and internal modeling oversight unfortunately are ideally suited to granting regulators the discretion they need to decide not to do their jobs when that becomes politically expedient.

As part of the discussion of capital requirements, it is also important for economists and regulators to recognize the prevalence and the shortcomings of ex post policies that are often used to deal with financial collapses, which often result from maintaining inadequate bank capital. Those include various kinds of loss-sharing arrangements between banks and taxpayers (including bank bailouts, debt forgiveness, forbearance of regulatory enforcement, and taxpayer-subsidized preferred stock injections into banks in reaction to loan losses). The lessons of recent experience strongly suggest that such ex post policy responses are extremely costly and often result from inadequate ex ante incentives to manage risk properly (for a review, see Calomiris, Laeven, and Klingebiel 2005). The recognition that generous safety net protections encourage excessive risk taking, and that this often results in extremely socially costly ex post interventions into the 
financial sector, offers a reason to set capital requirements higher ex ante than they would need to be in a truly laissez faire world.

The twin goals of (a) determining the right level of risk-based capital for the economy, and (b) finding a way to enforce capital standards if the amounts of capital chosen by private market discipline are inadequate, remain elusive, especially in the presence of generous government safety nets. The hardest challenge for financial economists is to devise models of the linkages among financial system credit, financial intermediaries' capital, financial intermediaries' risks, nonfinancial firms' asset prices, and macroeconomic activity that would be realistic enough to help us gauge the optimal risk-based capital ratio for the economy. The hardest challenge for policymakers is to find a way to enforce such policies credibly, while remaining flexible enough to permit activities with relatively low fundamental risks to avoid being penalized by the capital budgeting mandates of onesize-fits-all rules.

\section{References}

Barth, James, Gerard Caprio, and Ross Levine. 2004. Bank regulation and supervision: What works best. Journal of Financial Intermediation 13:205-48.

Brewer, Elijah, III, and Thomas H. Mondschean. 1993. Junk bond holdings, premium tax offsets, and risk exposure at life insurance companies. Federal Reserve Bank of Chicago Working Paper no. 93-3. Chicago: Federal Reserve Bank of Chicago.

Brewer, Elijah, III, Thomas H. Mondschean, and Philip E. Strahan. 1992. The effects of capital on portfolio risk at life insurance companies. Federal Reserve Bank of Chicago Working Paper no. 92-29. Chicago: Federal Reserve Bank of Chicago.

Calomiris, Charles W., Luc Laeven, and Daniela Klingebiel. 2005. Financial crisis policies and resolution mechanisms: A taxonomy from cross-country experience. In Systematic financial crises: Containment and resolution, ed. P. Hanohan and L. Laeven, 25-75. Cambridge: Cambridge University Press.

Calomiris, Charles W., and Joseph R. Mason. 1998. Comparing bank holding companies' risk-based capital to other financial intermediaries. Unpublished manuscript.

. 2003. Fundamentals, panics, and bank distress during the depression. American Economic Review (December): 1615-47.

. 2004. Credit card securitization and regulatory arbitrage. Journal of Financial Services Research (August): 5-28.

Calomiris, Charles W., and Andrew Powell. 2001. Can emerging market bank regulators establish credible discipline? The case of Argentina, 1992-99. In Prudential Supervision: What Works and What Doesn't, ed. F. S. Mishkin, 147-96. Chicago: University of Chicago Press.

Calomiris, Charles W., and Berry Wilson. 2004. Bank capital and portfolio management: The 1930s 'capital crunch' and the scramble to shed risk. Journal of Business (July): 421-55.

Diamond, Douglas W., and Phillip H. Dybvig. 1983. Bank runs, deposit insurance, and liquidity. Journal of Political Economy (June): 401-19.

Minton, Bernadette A., René M. Stulz, and Rohan Williamson. 2005. How much 
do banks use credit derivatives to reduce risk? NBER Working Paper no. 11579. Cambridge, MA: National Bureau of Economic Research, August.

Shadow Financial Regulatory Committee. 2000. Reforming bank capital regulation. Washington, DC: AEI Press.

Von Peter, Goetz. 2004. Asset prices and banking distress: A macroeconomic approach. BIS Working Paper no. 167. Basel, Switzerland: Bank for International Settlements.

\section{Discussion Summary}

Gary Gorton began the general discussion by questioning whether the amount of risk transferred from banks to insurance companies is as large as some statistics imply. Although credit derivative contracts may transfer risk, many securitizations receive implicit support from sponsors. He also questioned whether capital requirements can be binding in the long run, because banking business can move to nonbank financial institutions.

Martin Feldstein observed that economic capital considerations drive large-bank decision making, not regulatory capital requirements.

Anthony Saunders noted that the behavior of insurance companies (and other nonbank institutions) in bad states of the world is important to understanding systemic risk. Defaults by nonbanks, in addition to disrupting nonbank markets, could affect bank solvency. Peter Garber noted that U.S. insurance companies are subject to capital regulations, which are complicated, and that in bad states of the world insurance companies may gamble for redemption just like banks. Martin Feldstein observed that the guarantee funds that protect U.S. policyholders may strengthen moral hazard incentives of weak insurers. Surviving insurance companies must make up the losses imposed by those that fail.

When discussion turned to the experience of European insurance companies, Paul Kupiec noted that their losses in recent years were mainly driven by losses on their equity investments, which are much larger as a proportion of assets than at U.S. insurance companies. Philipp Hartmann agreed that equity losses were the first and primary source of loss, but noted that losses on credit derivatives were a material second leg of the double whammy they suffered.

Hayne Leland argued that credit derivatives might cause systemic problems for reasons other than those mentioned in Allen and Gale's paper. If dynamic hedging is used by protection sellers to hedge their credit derivative portfolios, increases in default rates may have knock-on effects in equity and bond markets, amplifying the price declines that are in any case likely to be associated with increased credit risk. Peter Garber agreed that such dynamic hedging is common in practice. 
In the course of the discussion, several participants mentioned the common wisdom that (a) many risk-transfer transactions by banks (securitizations, credit derivatives, and others) are "capital arbitrage" (intended primarily to reduce regulatory capital requirements), and (b) losses suffered by insurance companies on their investments in credit derivative contracts were due to insurance companies' lack of expertise in pricing credit risk. Richard Cantor noted that, at least in the United States, it is not clear that credit protection sellers lost money on the whole in the long run. Although their portfolios may have suffered mark-to-market losses during 20012003, when credit spreads were high, over the longer term the premiums they earn may more than compensate for payouts. Ken Abbott commented that concerns about the precision of credit risk pricing should be more general. He does not have great confidence in the credit risk pricing models he has seen used in practice. Most of the risk-transfer transactions he has seen have economic motivations and are not capital arbitrage. David Modest observed that at the time of the conference, the cyclical pendulum appeared to have swung to an excess of supply by protection sellers, forcing spreads down to unreasonable levels.

Commenting on some of the assumptions of the Allen and Gale model, Casper de Vries wondered if results would be different if capital regulation was useful rather than having no role in enhancing welfare. The assumption that regulation is binding in equilibrium may not be necessary for it to affect the equilibrium, as it might affect the value of off-equilibrium-path alternatives even if not binding. 
